\title{
Sensitive Detection of Fusarium circinatum in Pine Seed by Combining an Enrichment Procedure with a Real-Time Polymerase Chain Reaction Using Dual-Labeled Probe Chemistry
}

\author{
Renaud Ioos, Céline Fourrier, Gabriela Iancu, and Thomas R. Gordon
}

First, second, and third authors: Laboratoire National de la Protection des Végétaux, Station de mycologie, IFR 110 "Génomique, Ecophysiologie et Ecologie Fonctionnelles”, Domaine de Pixérécourt, F54220 Malzéville, France; fourth author: Department of Plant Pathology, University of California, Davis 95616. Accepted for publication 27 January 2009.

\begin{abstract}
Ioos, R., Fourrier, C., Iancu, G., and Gordon, T. R. 2009. Sensitive detection of Fusarium circinatum in pine seed by combining an enrichment procedure with a real-time polymerase chain reaction using dual-labeled probe chemistry. Phytopathology 99:582-590.

Fusarium circinatum is the causal agent of pitch canker disease on numerous Pinus spp. This aggressive fungus may infect pine seed cryptically and, therefore, can easily be spread long distances by the seed trade. F. circinatum has recently been listed as a quarantine organism in numerous countries throughout the world, which prompted the development of a specific and sensitive tool for the detection of this pathogen in conifer seed. A new detection protocol for $F$. circinatum based on a biological enrichment step followed by a real-time polymerase chain reaction (PCR) assay was developed. Several enrichment protocols were

was the most efficient technique to increase $F$. circinatum biomass before DNA extraction. The relative accuracy, specificity, and sensitivity of the real-time PCR assay was evaluated in comparison with a previously published conventional PCR test on 420 seed DNA extracts. The real-time PCR described here proved to be highly specific and significantly more sensitive than the conventional PCR, and enabled the detection of $F$. circinatum in samples artificially contaminated with less than $1 / 1,000$ infected seed, as well as in naturally infected samples. Last, in order to routinely check the quality of the seed DNA extracts, a primer-probe combination that targets a highly conserved region within the $18 \mathrm{~S}$ ribosomal DNA in plants or fungi was successfully developed. This assay allows for quick and reliable detection of $F$. circinatum in seed, which can help to prevent long-distance spread of the pathogen via contaminated seed lots.
\end{abstract} compared and a $72-\mathrm{h}$ incubation of the seed with potato dextrose broth
Fusarium circinatum Nirenberg \& O’Donnell (= F. subglutinans (Wollenw. \& Reinking) P. E. Nelson, Toussoun \& Marasas f. sp. pini Correll et al.) (teleomorph $=$ Gibberella circinata Nirenberg \& O'Donnell), is the causal agent of pitch canker disease. The fungus causes cankers that girdle branches, aerial roots, and even trunks of Pinus spp. Cankers are often associated with conspicuous and sometimes spectacular resin exudates ("pitch"). Multiple-branch infections may cause severe crown dieback and eventually lead to the death of the tree (17). The fungus can also cause root rot (16) and damping-off in seedlings (7). Pitch canker is damaging to many Pinus spp. with variable levels of severity $(20,26)$, and is also reported to affect Douglas fir (Pseudotsuga menziesii) $(21,22)$. This disease is a serious threat to pine forests wherever it occurs, by reducing growth and timber quality and causing extensive tree mortality (18).

F. circinatum is primarily a wound pathogen and enters the host through infection courts created by insects, silvicultural practices, or weather-related injuries. The fungus may move from tree to tree by aerial dispersion of conidia or be vectored by insects (23). However, long-distance dispersal will most likely result from transport of infected host material, such as seed (43). Pathogeninfested seed may be responsible for the establishment of pitch canker in California (23) and South Africa (10).

Pitch canker was first reported in North Carolina (United States) in 1946 (25) but has since spread throughout the south-

Corresponding author: R. Ioos; E-mail address: renaud.ioos@agriculture.gouv.fr

doi:10.1094/PHYTO-99-5-0582

(C) 2009 The American Phytopathological Society eastern United States and to California (17). The disease is also found in Japan (31), Mexico (24), and Chile (45) and has recently been reported as established $(13,29)$ or as eradicated (5) in Europe. Pitch canker poses a great threat to pine species in both native forests and plantations and there are only limited prospects for eradication of established infestations. Therefore, effective prophylactic measures to prevent spread of the fungus are of great importance. In particular, strict phytosanitary measures are required to prevent introduction of the pathogen via contaminated seed. To this end, several countries have implemented specific regulations regarding importation and movement of Pinus spp. and $P$. menziesii seed $(4,6)$. Reliable enforcement of such regulations depends on the application of rapid, specific, and sensitive detection tools. Detection by isolation of the pathogen in culture is labor intensive and identification based on morphological criteria $(11,33,35)$ demands specialized skills. Whereas molecular tools $(15,35,41)$ can mitigate the latter problem, none are yet adapted for direct detection of the pathogen in planta.

Real-time polymerase chain reaction (PCR) was first implemented for plant disease diagnosis in the late 1990s when it was used for detection of a bacterial pathogen on potato tubers (36). This methodology has since been widely applied to detection of fungal pathogens owing to its increased celerity, sensitivity, and specificity compared with conventional PCR assays (38). In addition, biological enrichment of the target organism may be used to facilitate detection of very low levels of bacterial (37) or fungal (40) contamination.

Recently, a pair of $F$. circinatum-specific PCR primers has been described and could be used in real-time PCR format with SYBR green fluorescent dye (39). These primers were initially designed 
to detect airborne spores of $F$. circinatum and were not evaluated on Pinus seed. Schweigkofler et al. (39) showed that the intergenic spacer (IGS) region of the nuclear ribosomal DNA on which these $F$. circinatum-specific PCR primers were based displayed enough variability to clearly discriminate between all the $F u$ sarium spp. phylogenetically close to $F$. circinatum, especially those belonging to "American Clade" of the G. fujikuroi complex sensu O'Donnell et al. (34). The IGS region is associated with ribosomal genes that are repeated in tandem in the genome of the Eukaryotes and up to 100 to 200 copies are present within a single nucleus (44). This high copy number makes IGS an ideal target sequence for a PCR test.

In this study, a different region of the $F$. circinatum IGS was selected to design a dual-labeled probe and a PCR primer pair to be used in a real-time PCR assay specific for this pathogen. In addition, a new combination of dual-labeled probe/primers that targets the 18S rDNA region in plant or fungal DNA was also designed, in order to verify the quality of each DNA extract. Last, several enrichment procedures as well as two widely used commercial plant DNA extraction kits were tested, in order to select the best protocol for accurate detection of low levels of $F$. circinatum on conifer seed. The real-time PCR test and a conventional PCR test (39) were applied to the same samples in order to validate the efficacy of the new procedure.

\section{MATERIALS AND METHODS}

Isolates. Isolates of $F$. circinatum used in this study were obtained from various culture collections (Table 1) and were maintained and manipulated in level 3 biohazard containment facilities, in compliance with EU Directive CE 95/44 (2). This study also included isolates of: (i) species phylogenetically close to $F$. circinatum, which are all anamorphic stages of G. fujikuroi (Sawada) Wollenw. (34); (ii) other species of Fusarium commonly encountered in soil or plant debris; and (iii) other fungi commonly found on conifers. Fungi were cultured in the dark at $22^{\circ} \mathrm{C}$ in potato dextrose broth (PDB) (Difco, Beckton, Dickinson and Co., Sparks, MD) for 5 days, after which 50 to $200 \mathrm{mg}$ of fresh mycelium was harvested and transferred into a 2-ml tube. Genomic DNA was extracted using a commercial plant DNA extraction kit (DNeasy plant mini kit; Qiagen, Courtaboeuf, France) following the manufacturer's instructions. DNA concentrations were estimated using a UV spectrophotometer (BioPhotometer; Eppendorf, Le Pecq, France).

Seed inoculation with $\boldsymbol{F}$. circinatum. Pinus nigra, $P$. pinaster, and Pseudotsuga menziesii seed free of $F$. circinatum were collected in seed orchards from different locations in France and provided by Vilmorin S.A. (La Ménitré, France). The first two Pinus spp. were chosen because, in Europe (Spain), F. circinatum has already been found on these species and on seed thereof (35). $P$. menziesii seed were used to assess the protocol with a different susceptible genus in the pine family. The seed of the three species were artificially inoculated with conidia of $F$. circinatum following the procedure described by Huang and Kuhlman (27) with slight modifications. Briefly, seed of Pinus spp. and P. menziesii were surface sterilized by soaking for $10 \mathrm{~min}$ in a solution containing $0.37 \% \mathrm{NaHClO}$ and $0.1 \%$ Tween 20 , followed by complete drying on a sterile filter paper under a laminar flow hood. $F$. circinatum isolate NRRL 25708 was cultured for 6 days on Spezieller Nährstoffarmer agar (SNA) medium, which enhances macro- and microconidia production in Fusarium spp. (32), under cool-white fluorescent lights with a 12-h light period. Microconidia were harvested by washing the surface of a culture with $10 \mathrm{ml}$ of deionized sterile water with $0.01 \%$ Tween 20 . The resulting suspension was diluted with sterile water to obtain a final density of $2 \times 10^{6}$ spores $/ \mathrm{ml}$, based on counts made using a haematocytometer. Seed were inoculated by soaking in the spore suspension for $10 \mathrm{~min}$, after which they were air dried overnight under a security hood. In all, 100 inoculated seeds for each tree species were arbitrarily selected and cultured on PDA at $22 \pm 3^{\circ} \mathrm{C}$ for 6 days. F. circinatum was observed to grow from $100 \%$ of the seed sampled for each tree species, confirming that the procedure provided uniform infestation of the treated seed.

Artificially contaminated Pinus nigra, P. pinaster, and Pseudotsuga menziesii seed samples were prepared by mixing $F$. circinatum-inoculated seed with $F$. circinatum-free seed. By this procedure, lots of 1,000 seeds were prepared with infestation levels ranging from $0.1 \%$ ( 1 contaminated seed and $999 \mathrm{~F}$. circinatum-free seeds) to $10.0 \%$. Negative control seed lots consisted of 1,000 F. circinatum-free seeds.

Fungal enrichment and DNA extraction from seed samples. The inoculated seed samples as well as the F. circinatum-free seed samples were subjected to four different biological enrichment procedures in order to increase the biomass of $F$. circinatum, if present. Each 1,000-seed sample was incubated at $22 \pm 3^{\circ} \mathrm{C}$ for 48 or $72 \mathrm{~h}$ in a sterile $175-\mathrm{cm}^{2}$ Easy flask (Nunc, Roskilde, Denmark) with $\approx 35 \mathrm{ml}$ of either PD broth or dichoran chloramphenicol peptone (DCP) broth. DCP is used as a semiselective medium for Fusarium spp. (1) and was prepared following the modified composition described by Ioos et al. (28) but omitting the agar, whereas PD broth is not selective and allows the growth of any cultivable fungus. After incubation, the content of the Easy flask (seed + broth) was transferred aseptically in a sterilized grinding bowl, and ground for 1 min using a Microtron MB 550 mixermill (Kinematica, Lucern, Switzerland). Four subsamplings of $500 \mu \mathrm{l}$ of grinding juice were collected using a micropipette and transferred into individual sterile 2-ml microtubes for total DNA extraction. For each seed sample, total DNA from two 500- $\mu$ l subsamplings were extracted using a DNeasy Plant minikit (Qiagen) and total DNA from the two other 500- $\mu$ l subsamplings were extracted using a Nucleospin Plant II miniprep (MachereyNagel, Hoerdt, France), both following the manufacturers' instructions. In order to prevent cross-contamination between samples, the mixer mill bowls were systematically sterilized after use by soaking and cleaning in a freshly prepared $2 \%$ sodium hypochlorite solution.

For each conifer species and for each infestation level, a nonenriched 1,000-seed sample was also prepared and directly ground in the mixer mill. Approximately $4 \times 500 \mu \mathrm{l}$ of ground powder was transferred into individual sterile 2-ml microtubes and processed as described above for DNA extraction. In total, 420 subsamples were therefore available for DNA testing, consisting of 360 prepared from $F$. circinatum-infected seed samples and 60 prepared from $F$. circinatum-free seed samples.

To compare the real-time PCR results obtained using different enrichment protocols and DNA extractions procedures, mean cycle threshold $(\mathrm{Ct})$ values were calculated such that all the $\mathrm{Ct}>$ 40 were taken as $=40$.

Analysis of naturally infected samples. More than 100 commercial seed samples originating from France, the United States, and northern Spain were analyzed by both real-time and conventional PCR. In addition, a series of seed samples collected from cones on symptomatic Pinus radiata in native stands on the Monterey Peninsula in California was also analyzed by both techniques. All the samples were directly submitted to a 72-h enrichment step in PD broth without any prior surface disinfection step. As a consequence, both the superficial and the internal F. circinatum propagules or mycelium might be detected. Following the biological enrichment, the samples were ground as described for the artificially infected samples and two 500- $\mu \mathrm{l}$ subsamples were collected for each sample. Total DNA was subsequently extracted and purified using the Nucleospin Plant II miniprep (Macherey-Nagel) as described above for the artificially infested samples and tested in triplicate by real-time (FCIR-F/-R/$\mathrm{P}$ and $18 \mathrm{~S}$ uni-F/-R/-P) and conventional (CIRC1A/CIRC4A) PCR. However, for these samples, the conventional PCR tests 
were conducted using a hybridization temperature of $66^{\circ} \mathrm{C}$, as described by Schweigkofler et al. (39).

Design of probes and primers. The IGS sequences for 26 isolates of Fusarium spp. phylogenetically close to F. circinatum and 7 isolates of $F$. circinatum were retrieved from GenBank and compared by multiple alignments using MultAlin program version 5.3.3 (14). A series of forward and reverse primer and probe combinations specific for $F$. circinatum were manually designed from several polymorphic regions, and their respective temperatures and potential secondary structures were evaluated using Beacon Designer software (Premier Biosoft, Palo Alto, CA) to screen out unsuitable combinations. Primers FCIR-F and FCIR-R and probe FCIR-P fulfilled the technical and thermodynamic requirements for a primer-hydrolysis probe combination for real-time PCR (12) and were finally retained based on their in silico and in vitro specificity. Their sequence and the reporterquencher dye combination for the hydrolysis probe are indicated in Table 2. A primer pair (18S uni-F/-R) and a dual-labeled probe (18S uni-P) were also designed to target a highly conserved region of the $18 \mathrm{~S}$ rDNA throughout a wide range of eukaryotic organisms (alignment data not shown), including tree species, herbaceous plants, or fungi (Table 2). This primer-probe combination was used in a real-time PCR assay to check the quality of the DNA extracted from any plant or fungal sample (Table 1) and to validate false-negative results potentially caused by inhibition or DNA shearing.

The $F$. circinatum-specific primer pair CIRC1A and CIRC4A (39) was also used in conventional PCR tests (Table 2).

All primers and probes were synthesized by Eurogentec (Seraing, Belgium).

PCR and real-time PCR conditions. The conventional PCR reactions using primer CIRC1A/CIRC4A were carried out with a GenAmp 9700 thermocycler (Applied Biosystems, Foster City, CA). The cycling profile and reaction mixture composition were those described by Schweigkofler et al. (39) but, after repetitive failures to amplify the target in artificially infested seed samples with low infestation levels, the annealing temperature initially set at $66^{\circ} \mathrm{C}$ (39) had to be decreased to $60^{\circ} \mathrm{C}$ (data not shown).

Real-time PCR reactions were performed with a Rotor-Gene 6500 (Corbett Research, Mortlake, Australia) set with an autogain optimization for each channel performed before the first fluores-

TABLE 1. List and characteristics of the organisms tested in this study and results following the real-time polymerase chain reaction assays targeting Fusarium circinatum intergenic spacer or the $18 \mathrm{~S}$ rDNA region

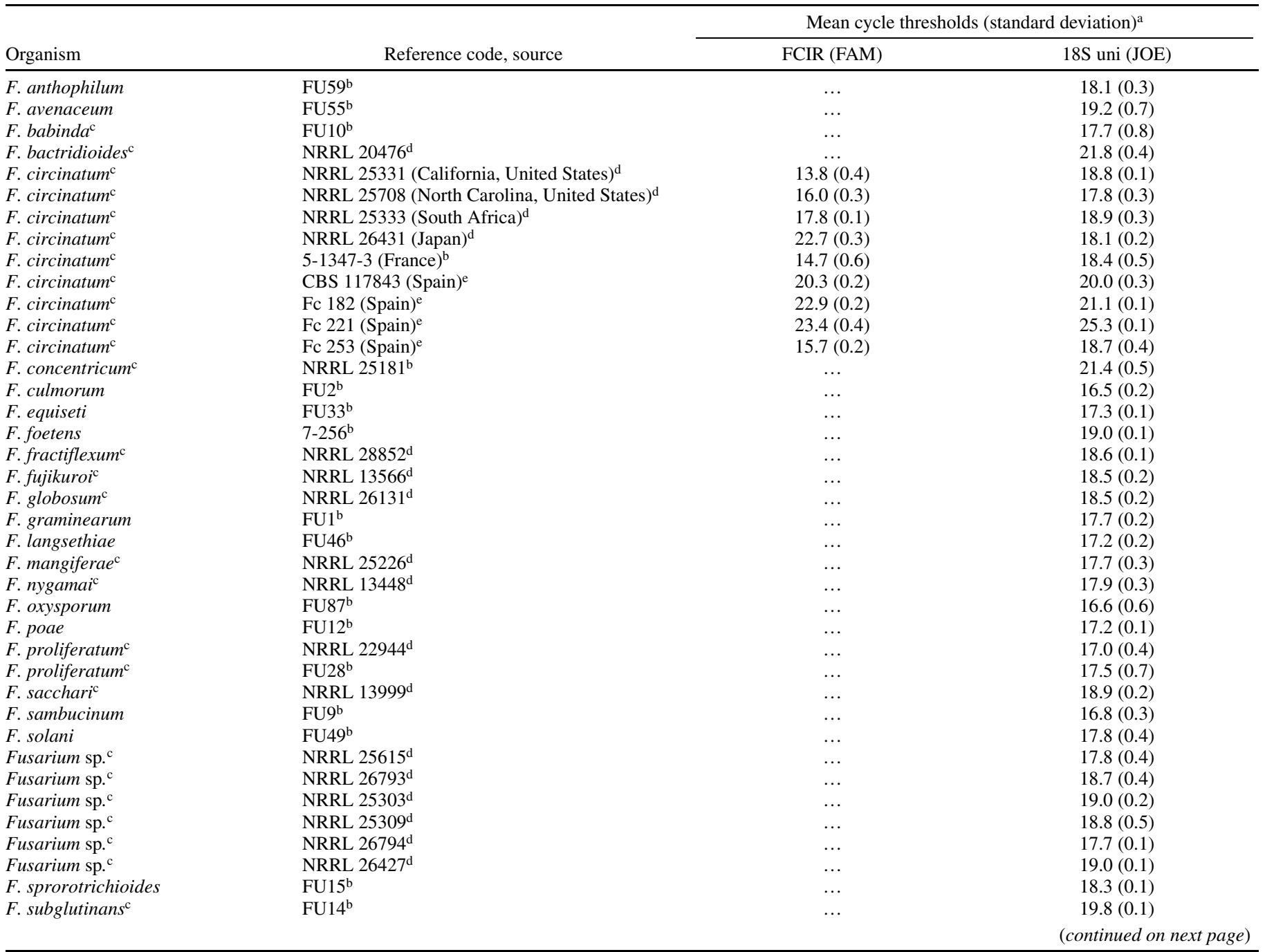

a Cycle thresholds were computed with all the DNA extracts normalized to $0.4 \mathrm{ng} \mu^{-1}$.

${ }^{\mathrm{b}} \mathrm{LNPV}=$ station de mycologie, France.

${ }^{\mathrm{c}}$ Member of the Gibberella fujukuroi complex.

d K. O’Donnell, United States Department of Agriculture, Illinois.

e A. M. Pérez-Sierra, Universidad politécnica de Valencia, Spain.

f Species frequently isolated from Pinus or Pseudotsuga seed. 
cence acquisition. For monoplex $F$. circinatum or $18 \mathrm{~S}$-uni assays, amplifications were carried out in $20-\mu$ reaction volumes using the qPCR Core kit No ROX (Eurogentec) and consisting of molecular-grade water, $1 \times$ reaction buffer, $5 \mathrm{mM} \mathrm{MgCl}, 4 \times 0.2 \mathrm{mM}$ dNTPs, $0.3 \mu \mathrm{M}$ respective forward and reverse primer, $0.1 \mu \mathrm{M}$ respective dual-labeled probe, $0.5 \mathrm{U}$ of Amplitaq Gold, and $2 \mu \mathrm{l}$ of template DNA (0.8 to $30 \mathrm{ng}$ ).

The real-time PCR cycling conditions for both assays included an initial denaturation step at $95^{\circ} \mathrm{C}$ for $10 \mathrm{~min}$ followed by 40 cycles of denaturation for $15 \mathrm{~s}$ at $95^{\circ} \mathrm{C}$, and annealing-elongation for $55 \mathrm{~s}$ at 70 or $65^{\circ} \mathrm{C}$ for $F$. circinatum and $18 \mathrm{~S}$ uni, respectively. The $\mathrm{Ct}$ value for each reaction was determined using the RotorGene software version 1.7.75. Each sample DNA extract was tested in triplicate and a standard deviation was computed.

Comparative testing of seed samples. All 420 seed sample DNA extracts used for evaluation of the enrichment and DNA extraction protocols were tested by both conventional PCR using CIRC1A/CIRC4A primers and by the real-time primers and duallabeled probes developed in this study. Because these samples were artificially inoculated, the contamination status of the samples (+ or - ) was known and the latter were considered to be standard samples for evaluation and validation of the conventional and real-time PCR tests. The results were assigned into a concordance correlation table and processed according to McClure (30) and ISO 16140 (3) to compute the relative accuracy (AC), specificity (SP), and selectivity (SE) and their respective confidence intervals (CIs).

\section{RESULTS}

Assessment of the specificity of primers and probes. IGS sequences publicly available on GenBank, including Fusarium spp. phylogenetically close to $F$. circinatum, were first tested with the FCIR-F/-R/-P sequences by BLAST analyses (available online from the National Center for Biotechnology Information). Perfect annealing of all three primers-probe combinations (100\% homology) was only obtained with $F$. circinatum sequences (accessions AY249397 to AY249403 and AJ879950), thus supporting the in silico specificity of this primer-probe combination inferred from sequence alignment (data not shown).

The combination of primers FCIR-F and FCIR-R with the duallabeled probe FCIR-P was then tested in real-time PCR with a series of DNA extracts from a wide range of Fusarium spp., including anamorphic stages of G. fujikuroi, which are close rela-

\begin{tabular}{|c|c|c|c|}
\hline \multirow[b]{2}{*}{ Organism } & \multirow[b]{2}{*}{ Reference code, source } & \multicolumn{2}{|c|}{ Mean cycle thresholds (standard deviation) ${ }^{\mathrm{a}}$} \\
\hline & & FCIR (FAM) & $18 \mathrm{~S}$ uni (JOE) \\
\hline F. subglutinans ${ }^{\mathrm{c}}$ & NRRL 22016 & $\ldots$ & $18.6(0.7)$ \\
\hline F. thapsinum ${ }^{\mathrm{c}}$ & NRRL 22045 & $\ldots$ & $18.2(0.1)$ \\
\hline F. torulosum & FU67 ${ }^{b}$ & $\ldots$ & $18.2(0.6)$ \\
\hline F. tricinctum & FU11 ${ }^{b}$ & $\ldots$ & $18.5(0.9)$ \\
\hline F. venenatum & FU36 ${ }^{b}$ & $\ldots$ & $16.9(0.5)$ \\
\hline F. verticillioides ${ }^{\mathrm{c}}$ & NRRL 22172d & $\ldots$ & $18.6(0.6)$ \\
\hline F. verticillioides ${ }^{\mathrm{c}}$ & FU86 ${ }^{\mathrm{b}}$ & $\ldots$ & $17.7(0.2)$ \\
\hline Aspergillus niger $\mathrm{f}$ & 7-9906a ex Pinus seed ${ }^{\mathrm{b}}$ & $\ldots$ & $19.3(0.2)$ \\
\hline Fusicoccum sp. & 7-1351a ex conifer ${ }^{\mathrm{b}}$ & $\ldots$ & $19.7(0.2)$ \\
\hline Melampsora larici-populina & Teliospores $^{\mathrm{b}}$ & $\ldots$ & $17.2(0.2)$ \\
\hline Mucor sp. ${ }^{\mathrm{f}}$ & 7-9906a ex Pinus seed ${ }^{\mathrm{b}}$ & $\ldots$ & $20.1(0.1)$ \\
\hline Penicillium expansum ${ }^{\mathrm{f}}$ & 7-9906a ex Pinus seed ${ }^{\mathrm{b}}$ & $\ldots$ & $21.3(0.6)$ \\
\hline Phomopsis sp. & 7-1399 ex conifer ${ }^{b}$ & $\ldots$ & $16.5(0.2)$ \\
\hline Sphaeropsis sapinea & 7-1387 ex conifer ${ }^{b}$ & $\ldots$ & $17.8(0.3)$ \\
\hline Trichoderma sp. ${ }^{\mathrm{f}}$ & 7-9906a ex Pinus seed ${ }^{\mathrm{b}}$ & $\ldots$ & $19.3(0.2)$ \\
\hline Truncatella sp. & 7-1351b ex conifer ${ }^{b}$ & $\ldots$ & $20.3(0.6)$ \\
\hline Alnus glutinosa & Subcortical tissue & $\ldots$ & $15.0(0.7)$ \\
\hline Aucuba sp. & Subcortical tissue & $\ldots$ & $18.4(0.6)$ \\
\hline Arbutus sp. & Subcortical tissue & $\ldots$ & $15.4(0.1)$ \\
\hline Camelia sp. & Leaf & $\ldots$ & $15.3(0.9)$ \\
\hline Citrus sinensis & Fruit & $\ldots$ & $16.0(0.1)$ \\
\hline Cornus sp. & Subcortical tissue & $\ldots$ & $16.1(0.5)$ \\
\hline Escallonia sp. & Leaf & $\ldots$ & $16.5(0.4)$ \\
\hline Fragaria $\times$ ananassa & Roots & $\ldots$ & $15.4(0.8)$ \\
\hline Helianthus annuus & Seed & $\ldots$ & $15.7(0.3)$ \\
\hline Kalmia sp. & Subcortical tissue & $\ldots$ & $16.8(0.1)$ \\
\hline Laurus nobilis & Leaf & $\ldots$ & $16.4(0.6)$ \\
\hline Lycopersicon esculentum & Stem & $\ldots$ & $13.2(0.2)$ \\
\hline Malus domestica & Fruit & $\ldots$ & $15.2(0.2)$ \\
\hline Pieris sp. & Subcortical tissue & $\ldots$ & $16.6(0.3)$ \\
\hline Pinus pinaster & Subcortical tissue & $\ldots$ & $18.2(0.5)$ \\
\hline Pinus pinaster & Seed & $\ldots$ & $17.0(0.7)$ \\
\hline Pinus nigra & needles & $\ldots$ & $16.1(0.2)$ \\
\hline Pinus nigra & Seed & $\ldots$ & $17.2(0.9)$ \\
\hline Pyrus sp. & Leaf & $\ldots$ & $16.9(0.8)$ \\
\hline Populus deltoides & Leaf & $\ldots$ & $14.9(0.7)$ \\
\hline Prunus persica & Fruit & $\ldots$ & $12.5(0.5)$ \\
\hline Pseudotsuga menziesii & Seed & $\ldots$ & $15.6(0.4)$ \\
\hline Quercus sp. & Subcortical tissue & $\ldots$ & $16.2(0.8)$ \\
\hline Rhododendron sp. & Leaf & $\ldots$ & $13.5(0.6)$ \\
\hline Rosa sp. & Subcortical tissue & $\ldots$ & $14.1(0.8)$ \\
\hline Rosmarinus sp. & Subcortical tissue & $\ldots$ & $15.0(0.6)$ \\
\hline Syringa sp. & Subcortical tissue & $\ldots$ & $16.6(0.3)$ \\
\hline Taxus sp. & Subcortical tissue & $\ldots$ & $14.4(0.6)$ \\
\hline Vitis vinifera & Leaf & $\ldots$ & $14.6(0.2)$ \\
\hline Vaccinum sp. & Subcortical tissue & $\ldots$ & $14.6(0.9)$ \\
\hline Viburnum sp. & Subcortical tissue & $\ldots$ & $15.1(0.6)$ \\
\hline
\end{tabular}


tives of $F$. circinatum (39). Real-time reactions using this primerprobe combination proved to be highly specific, because low $\mathrm{Ct}$ values were obtained for all $F$. circinatum isolates, regardless of their geographical origin, and not for isolates of any other fungal species or for plant DNA (Table 1). In addition, a positive signal was consistently obtained in real-time PCR using the $18 \mathrm{~S}$ uni-F/ -R/-P combination with all DNA extracts tested, thus confirming their amplifiability (Table 1). The DNA extracts from various plant species were all successfully amplified by this $18 \mathrm{~S}$ uni-F/ -R/-P combination, showing its usefulness for universal DNA extraction quality control.

Efficiency and sensitivity of the PCR assays. The sensitivity of the FCIR-F/-R/-P combination was measured with a 10-fold dilution series of $F$. circinatum isolate NRRL 25331 DNA in deionized DNA-free water, to yield final concentrations ranging

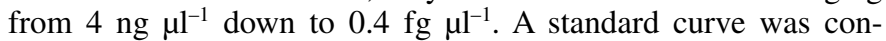
structed and the corresponding amplification efficiency was 1.01 (Fig. 1). Assay results showed a linear relationship between $\mathrm{Ct}$ values and $\log$ (initial concentration of the target) down to a con-

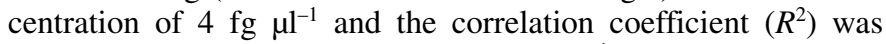
0.99 . The limit of detection was $0.4 \mathrm{fg}^{-1} \mathrm{l}^{-1}$ but fell outside the linear response of the assay. The optimized sequences of FCIR$\mathrm{F} /-\mathrm{R} /-\mathrm{P}$ made it possible to run the real-time PCR under highstringency conditions (annealing or elongation at $70^{\circ} \mathrm{C}$ ), thus ensuring maximum specificity with no significant effect on the amplification yield (data not shown).
Comparison between conventional and real-time PCR. Following the real-time PCR test with the FCIR-F/-R/-P combination, samples yielding a $\mathrm{Ct}$ value $<40$ were judged as positive. Likewise, samples yielding a $\approx 360$-bp band with the conventional CIRC1A/CIRC4A PCR test were considered to be positive. However, PCR runs using a $66^{\circ} \mathrm{C}$ annealing temperature (39) yielded few positive signals with templates from artificially contaminated seed samples. Consequently, the CIRC1A/CIRC4A PCR tests were run under lowered stringency conditions (an annealing temperature of $60^{\circ} \mathrm{C}$ ) in order to obtain positive signals with these samples (Table 3).

The accuracy, selectivity, and sensitivity of both PCR and realtime PCR for the detection of $F$. circinatum were computed according to ISO 16140 (3). All 420 DNA extracts produced a positive signal following the $18 \mathrm{~S}$ uni-F/-R/-P real-time PCR test (Ct values of 9.7 to 21.5; data not shown), thereby confirming that they contained amplifiable DNA, and all were included in the statistical analyses. No false-positive results were obtained with negative controls, indicating that the relative specificity values were excellent (100\%) for both the real-time and conventional PCR test (Table 4). By contrast, the relative sensitivity values were clearly in favor of real-time PCR with 79.1 versus $58.6 \%$ for conventional PCR (Table 4). The relative accuracy of the tests was greater with real-time $(82.1 \%)$ than with conventional $(64.5 \%)$ PCR. Regardless of the enrichment protocol and the DNA extraction procedure, the real-time PCR test appeared consistently more

TABLE 2. Primers and dual-labeled probes tested in this study

\begin{tabular}{|c|c|c|c|c|c|}
\hline Target & Primer or probe & Sequence $\left(5^{\prime}-3^{\prime}\right)^{\mathrm{a}}$ & $\operatorname{Tm}\left({ }^{\circ} \mathrm{C}\right)$ & DNA region ${ }^{\mathrm{b}}$ & Product size (bp) \\
\hline \multirow[t]{3}{*}{ Fusarium circinatum } & FCIR-F & TCGATGTGTCGTCTCTGGAC & 57.2 & IGS & 146 \\
\hline & FCIR-R & CGATCCTCAAATCGACCAAGA & 56.1 & $\ldots$ & $\ldots$ \\
\hline & FCIR-P & [6-FAM]-CGAGTCTGGCGGGACTTTGTGC-[BHQ1] & 64.6 & $\ldots$ & $\ldots$ \\
\hline & $18 \mathrm{~S}$ uni-R & CCACCACCCATAGAATCAAGA & 55.3 & $\ldots$ & $\ldots$ \\
\hline & $18 \mathrm{~S}$ uni-P & [JOE]-ACGGAAGGGCACCACCAGGAGT-[BHQ1] & 66.3 & $\ldots$ & $\ldots$ \\
\hline \multirow[t]{2}{*}{ F. circinatum } & CIRC1A ${ }^{c}$ & CTTGGCTCGAGAAGGG & 49.0 & IGS & 360 \\
\hline & CIRC $4 \mathrm{~A}^{\mathrm{c}}$ & АССТАСССТАСАССТСТСАСТ & 56.1 & $\ldots$ & $\ldots$ \\
\hline
\end{tabular}

${ }^{a}$ 6-FAM = 6-carboxyfluorescein, BHQ1 = Black Hole Quencher 1, registered trademark of Biosearch Technologies, Inc., and JOE = 6-carboxy-4,5-dichloro-2,7dimethoxyfluorescein.

${ }^{\mathrm{b}}$ IGS = intergenic spacer.

${ }^{c}$ Schweigkofler et al. (39).

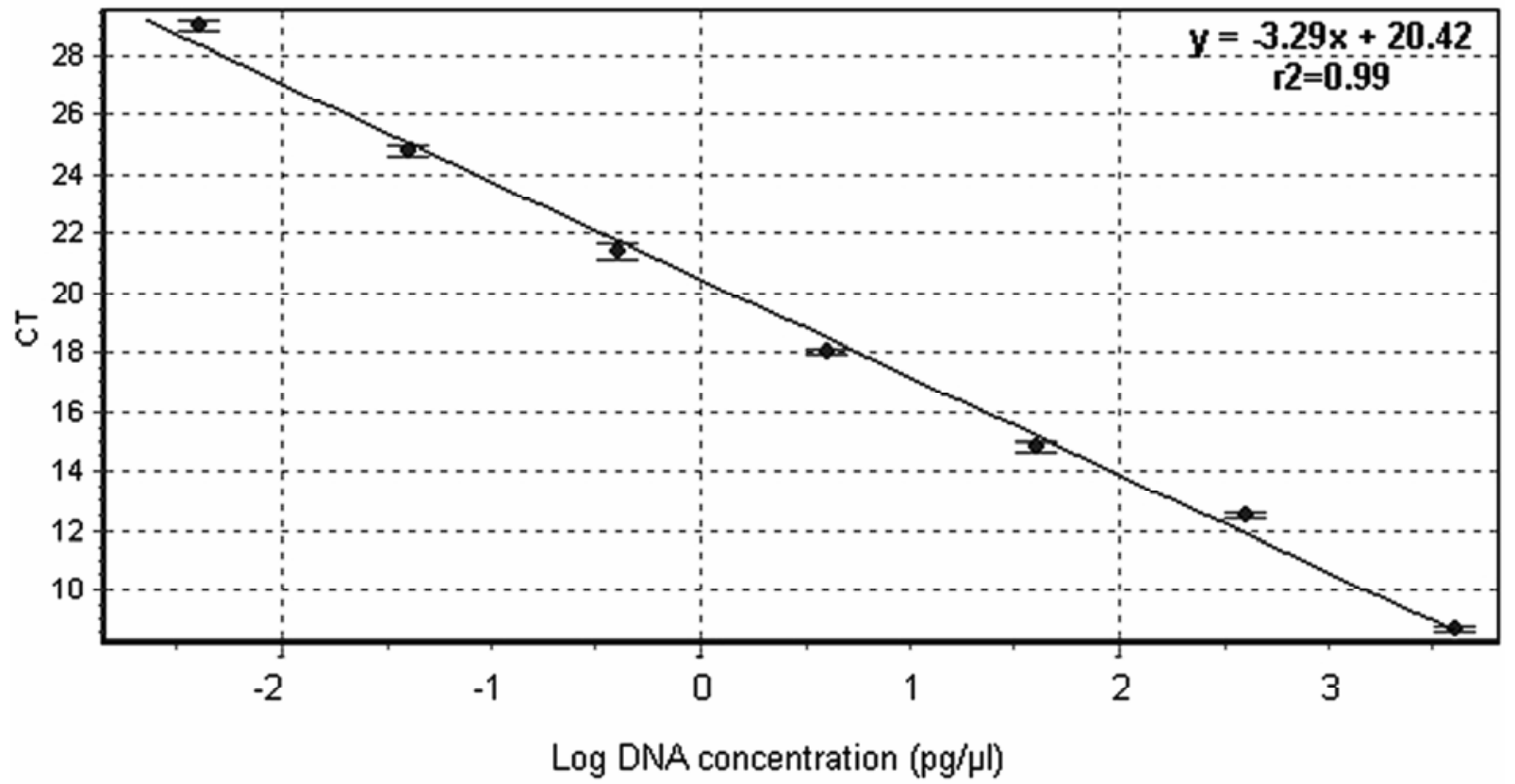

Fig. 1. Standard curve and correlation coefficient assessed with dilution of Fusarium circinatum DNA for real-time polymerase chain reaction using the primerprobe combination FCIR-F/-R/-P. Total DNA of the pathogen was diluted in molecular-grade water to yield final concentrations ranging from $4 \mathrm{ng}_{\mu 1}^{-1}$ to 4 fg $_{\mu l}{ }^{-1}$. 


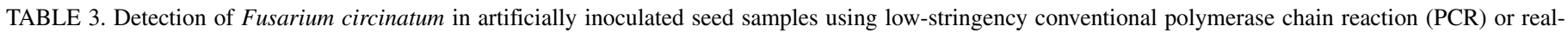
time PCR, following different enrichment procedures and using different commercial DNA extraction kits

\begin{tabular}{|c|c|c|c|c|c|c|c|c|c|c|c|c|c|c|c|}
\hline \multirow[b]{3}{*}{ Seed, enrichment ${ }^{\mathrm{a}}$} & \multirow[b]{3}{*}{$\mathrm{DNA}^{\mathrm{b}}$} & \multicolumn{14}{|c|}{ Infestation level $^{\mathrm{c}}$} \\
\hline & & \multicolumn{2}{|c|}{100} & \multicolumn{2}{|c|}{50} & \multicolumn{2}{|c|}{10} & \multicolumn{2}{|c|}{5} & \multicolumn{2}{|c|}{2} & & & 0 & \\
\hline & & Con. & Real & Con. & Real & Con. & Real & Con. & Real & Con. & Real & Con. & Real & Con. & Real \\
\hline Pinus pinaster & & & & & & & & & & & & & & & \\
\hline No & Q & + & 39.1 & + & 39.2 & + & 37.3 & - & - & - & - & - & - & - & - \\
\hline & & - & 37.5 & - & - & - & - & - & - & - & - & - & - & - & - \\
\hline & $\mathrm{MN}$ & + & 32.1 & + & 33.5 & + & 33.2 & + & 32.1 & - & 35.4 & - & 39.7 & - & - \\
\hline & & + & 31.8 & + & 33.1 & + & 32.8 & + & 33.2 & - & 34.0 & - & 36.6 & - & - \\
\hline DCPB $48 \mathrm{~h}$ & Q & + & 37.7 & - & 37.5 & - & - & - & - & - & - & - & 34.7 & - & - \\
\hline & & + & 37.1 & + & 38.2 & - & - & - & - & - & - & - & 38.1 & - & - \\
\hline & $\mathrm{MN}$ & + & 25.9 & + & 26.6 & + & 27.4 & + & 31.2 & - & 35.0 & - & 33.4 & - & - \\
\hline & & + & 26.3 & + & 26.9 & + & 27.6 & - & 30.7 & - & 32.9 & - & 33.6 & - & - \\
\hline DCPB $72 \mathrm{~h}$ & Q & + & 38.8 & + & 38.2 & - & - & - & - & - & - & + & 30.5 & - & - \\
\hline & & + & 36.9 & + & 37.8 & - & - & - & - & - & - & - & - & - & - \\
\hline & $\mathrm{MN}$ & + & 25.0 & + & 25.5 & + & 27.6 & + & 21.2 & + & 33.3 & + & 27.1 & - & - \\
\hline & & + & 24.1 & + & 24.9 & + & 26.4 & + & 21.0 & + & 33.6 & + & 27.7 & - & - \\
\hline PDB $48 \mathrm{~h}$ & Q & + & 34.2 & - & 36.6 & - & - & - & - & - & - & - & 36.0 & - & - \\
\hline & & + & 35.0 & + & 34.2 & - & - & - & - & - & - & - & 37.1 & - & - \\
\hline & $\mathrm{MN}$ & + & 24.3 & + & 25.5 & + & 27.8 & - & 30.4 & - & 36.6 & - & 35.3 & - & - \\
\hline & & + & 24.9 & + & 25.1 & + & 27.9 & - & 30.8 & - & 37.9 & - & 37.9 & - & - \\
\hline PDB $72 \mathrm{~h}$ & Q & + & 31.0 & + & 31.1 & - & 33.6 & - & 34.2 & - & 36.6 & - & 38.1 & - & - \\
\hline & & + & 29.9 & + & 31.5 & - & 33.1 & - & 34.6 & - & 36.9 & - & - & - & - \\
\hline & $\mathrm{MN}$ & + & 22.0 & + & 23.5 & + & 24.4 & + & 25.1 & + & 27.8 & + & 31.3 & - & - \\
\hline & & + & 22.5 & + & 22.9 & $+^{\mathrm{d}}$ & 23.9 & + & 22.1 & + & 26.5 & - & 31.9 & - & - \\
\hline P. nigra & & & & & & & & & & & & & & & \\
\hline No & Q & + & 38.2 & - & - & - & - & - & - & - & - & - & - & - & - \\
\hline & & - & 37.9 & - & - & - & - & - & - & - & - & - & - & - & - \\
\hline & $\mathrm{MN}$ & + & 33.0 & + & 34.2 & + & 34.7 & + & 34.1 & + & 34.1 & - & 36.4 & - & - \\
\hline & & + & 32.1 & + & 32.5 & + & 31.1 & - & 37.6 & - & 33.9 & - & 36.8 & - & - \\
\hline DCPB $48 \mathrm{~h}$ & Q & + & 35.5 & + & 38.8 & - & - & + & 36.2 & + & 36.2 & - & - & - & - \\
\hline & & + & 36.7 & + & 38.6 & - & - & - & - & + & 35.7 & - & - & - & - \\
\hline & $\mathrm{MN}$ & + & 24.9 & + & 25.8 & + & 25.8 & + & 28.3 & + & 29.6 & + & 33.7 & - & - \\
\hline & & + & 24.3 & + & 25.5 & $+^{\mathrm{d}}$ & 27.9 & + & 28.0 & + & 28.4 & - & 33.3 & - & - \\
\hline DCPB $72 \mathrm{~h}$ & Q & + & 33.9 & - & 35.8 & - & - & - & - & + & 32.5 & - & - & - & - \\
\hline & & + & 35.0 & + & 36.2 & - & - & - & - & + & 31.9 & - & 33.1 & - & - \\
\hline & $\mathrm{MN}$ & + & 25.5 & + & 26.5 & + & 29.9 & + & 34.2 & + & 21.9 & + & 30.2 & - & - \\
\hline & & + & 22.9 & + & 27.0 & + & 27.5 & + & 29.3 & + & 24.3 & + & 32.0 & - & - \\
\hline PDB $48 \mathrm{~h}$ & Q & + & 31.9 & + & 33.9 & + & 35.0 & - & 38.9 & - & 37.5 & - & - & - & - \\
\hline & & + & 31.0 & + & 33.8 & + & 39.1 & - & 36.9 & - & - & - & - & - & - \\
\hline & $\mathrm{MN}$ & + & 31.8 & + & 33.8 & + & 35.8 & + & 32.0 & + & 34.3 & - & 37.2 & - & - \\
\hline & & + & 31.4 & + & 33.5 & + & 33.1 & $+^{\mathrm{d}}$ & 33.0 & - & 34.5 & - & 38.3 & - & - \\
\hline PDB $72 \mathrm{~h}$ & Q & + & 24.8 & + & 25.8 & + & 23.5 & - & 26.0 & - & 26.3 & - & 24.1 & - & - \\
\hline & & + & 24.7 & + & 24.6 & - & - & - & - & - & - & - & 25.4 & - & - \\
\hline & $\mathrm{MN}$ & + & 20.8 & + & 21.9 & + & 22.5 & + & 22.3 & + & 24.1 & + & 22.9 & - & - \\
\hline & & + & 20.6 & + & 21.8 & + & 22.6 & + & 21.7 & + & 23.0 & + & 22.6 & - & - \\
\hline Pseudotsuga menzi & & & & & & & & & & & & & & & \\
\hline No & Q & + & 39.2 & - & 38.1 & + & 36.8 & - & - & - & - & - & - & - & - \\
\hline & & + & 37.5 & + & 37.9 & + & 35.5 & - & - & - & - & - & - & - & - \\
\hline & $\mathrm{MN}$ & + & 31.1 & + & 31.9 & + & 32.6 & + & 35.3 & + & 36.4 & + & 36.5 & - & - \\
\hline & & + & 30.1 & + & 31.0 & + & 32.7 & + & 34.0 & + & 36.9 & + & 38.8 & - & - \\
\hline DCPB $48 \mathrm{~h}$ & Q & + & 28.3 & + & 31.6 & + & 36.9 & - & - & - & 37.9 & - & - & - & - \\
\hline & & + & 30.1 & + & 31.5 & - & - & - & - & - & 37.0 & - & 38.4 & - & - \\
\hline & $\mathrm{MN}$ & + & 28.2 & + & 29.2 & + & 32.7 & + & 30.7 & + & 32.9 & - & 37.7 & - & - \\
\hline & & + & 27.6 & + & 29.8 & + & 33.0 & + & 30.6 & + & 32.5 & + & 39.3 & - & - \\
\hline DCPB $72 \mathrm{~h}$ & Q & + & 36.7 & - & 39.9 & - & - & - & - & - & 38.3 & - & - & - & - \\
\hline & & - & 36.2 & - & 39.8 & - & - & - & - & - & 39.1 & - & - & - & - \\
\hline & $\mathrm{MN}$ & + & 29.9 & + & 32.2 & - & 34.5 & + & 35.3 & $+^{\mathrm{d}}$ & 37.1 & - & - & - & - \\
\hline & & + & 31.0 & - & 32.5 & + & 35.8 & + & 36.1 & $+^{\mathrm{d}}$ & 38.5 & - & 38.1 & - & - \\
\hline PDB $48 \mathrm{~h}$ & Q & $+^{\mathrm{d}}$ & 32.5 & + & 32.6 & + & 34.7 & - & 34.2 & + & 35.3 & - & 35.4 & - & - \\
\hline & & $+^{\mathrm{d}}$ & 32.9 & + & 31.6 & - & 34.8 & - & 35.4 & - & 34.8 & - & 36.6 & - & - \\
\hline & $\mathrm{MN}$ & + & 29.6 & + & 31.4 & + & 33.1 & + & 36.9 & - & 36.1 & - & 37.1 & - & - \\
\hline & & + & 29.5 & - & 31.2 & + & 34.4 & - & 36.6 & + & 35.5 & - & 36.1 & - & - \\
\hline PDB $72 \mathrm{~h}$ & Q & + & 34.2 & + & 31.7 & - & - & + & 38.7 & - & - & - & 37.3 & - & - \\
\hline & & + & 33.4 & + & 34.1 & + & 33.9 & - & - & - & - & - & 36.2 & - & - \\
\hline & $\mathrm{MN}$ & + & 26.6 & + & 28.9 & $+^{\mathrm{d}}$ & 31.6 & $+^{\mathrm{d}}$ & 31.2 & + & 33.6 & + & 35.1 & - & - \\
\hline & & + & 25.9 & + & 28.2 & $+^{\mathrm{d}}$ & 31.3 & $+^{\mathrm{d}}$ & 31.6 & $+^{\mathrm{d}}$ & 32.7 & + & 37.7 & - & - \\
\hline
\end{tabular}

${ }^{a}$ DCPB = dichloran chloramphenicol peptone broth and PDB = potato dextrose broth.

b DNA extraction by Qiagen Plant DNeasy (Q) or Macherey-Nagel Plant II (MN) methods.

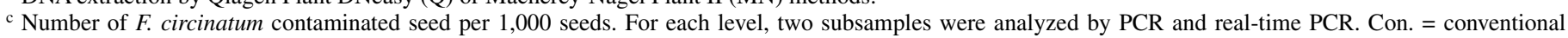

PCR; for each infestation level, + indicates that an amplicon of $360 \mathrm{bp}$ was obtained and - indicates that no amplicon was observed. Real = real-time PCR; mean cycle threshold $(\mathrm{Ct})$ value was calculated with triplicates and no $\mathrm{Ct}$ value generated before 40 cycles was rated as negative.

d Samples that yielded a positive signal under the PCR conditions described by Schweigkofler et al. (39). 
sensitive because it yielded Ct values with 43 of 60 DNA templates corresponding to seed samples containing a single $F$. circinatum-infected seed, whereas the conventional PCR gave positive results for only 14 of these 60 DNA templates.

Based on these results, only real-time PCR was used for comparisons of enrichment and DNA extraction protocols.

Evaluation of the enrichment and DNA extraction protocols. Statistically significant differences were observed between seed treatments applied before DNA extraction $(F=17.84, P<$ $0.0001)$. All enrichment procedures significantly enhanced the sensitivity of real-time PCR tests relative to tests without an enrichment step (Table 3). The lowest infestation levels were detected with a 72-h incubation period in PD broth, regardless of the pine species or the DNA extraction protocol used (Table 3). Averaged over 360 DNA templates obtained from $F$. circinatuminfested seed samples, mean $\mathrm{Ct}$ values were $33.7 \pm 5.1,33.9 \pm$ $5.9,34.5 \pm 3.8$, and $29.7 \pm 6.2$ after incubation for $48 \mathrm{~h}$ in DCP broth $(n=72)$, DCP broth for $72 \mathrm{~h}(n=72)$, PD broth for $48 \mathrm{~h}$ $(n=72)$, and PD broth for $72 \mathrm{~h}(n=72)$, respectively, whereas the mean $\mathrm{Ct}$ value reached $36.7 \pm 3.2(n=72)$ without an enrichment step. Likewise, under the conditions of the tests, DNA extraction carried out from seed samples ( $n=180$ each) with the MachereyNagel plant II kit yielded a significantly lower mean $\mathrm{Ct}$ value $(30.5 \pm 3.8)$ than with the Qiagen DNeasy plant $(36.9 \pm 2.7)$, regardless of the plant and of the enrichment procedure $(t=13.7$, $P<0.0001$ ).

Finally, the efficiency of the FCIR-F/-R/-P real-time PCR was not significantly affected by the nature of the conifer seed $(F=$ $0.92, P=0.4)$. Based on 360 DNA templates obtained from $F$. circinatum-infested seed samples, mean $\mathrm{Ct}$ values were $33.4 \pm$ 5.8, $32.5 \pm 6.2$, and $35.1 \pm 3.7$, with $P$. pinaster $(n=120)$, P. nigra $(n=120)$, and Pseudotsuga menziesii $(n=120)$, respectively.

Analysis of seed samples from naturally infected pine. In order to assess the specificity of the primers used in this study, PCR products obtained from two naturally infected seed samples were cloned and sequenced (Table 5). Because the dual-labeled probe is a hydrolysis probe, it is not incorporated into the PCR product, which is not the case with the forward and reverse primers. As a consequence, the forward and reverse primer sequences were trimmed before the blast analysis. The truncated sequences obtained were $100 \%$ identical and one of them was subsequently blasted on the GenBank database. Over its 105-bp

TABLE 4. Evaluation of the accuracy, sensitivity, and specificity of the FCIR real-time polymerase chain reaction (PCR) diagnostic developed in this study and of a conventional PCR test using CIRC1A/CIRC4A primers with a panel of 420 seed DNA extracts ${ }^{\mathrm{a}}$

\begin{tabular}{|c|c|c|c|c|c|c|}
\hline Method $^{\mathrm{b}}$ & Results & $\begin{array}{c}\text { Fusarium circinatum- } \\
\text { inoculated samples }(+)^{\mathrm{c}}\end{array}$ & $\begin{array}{c}\text { Negative } \\
\text { controls }(-)^{\mathrm{d}}\end{array}$ & Sensitivity $(\%)^{\mathrm{e}}$ & Specificity $(\%)^{\mathrm{f}}$ & Accuracy $(\%)^{\mathrm{g}}$ \\
\hline \multirow[t]{2}{*}{ Conventional PCR } & Positive (+) & $\mathrm{PA}=211$ & $\mathrm{PD}=0$ & $58.6( \pm 5.2)$ & $100.00(>98)$ & $64.5( \pm 4.7)$ \\
\hline & Negative (-) & $\mathrm{ND}=139$ & $\mathrm{NA}=60$ & & & \\
\hline & Negative (-) & $\mathrm{ND}=75$ & $\mathrm{NA}=60$ & $\ldots$ & $\ldots$ & $\ldots$ \\
\hline
\end{tabular}

a Numbers in parentheses: $95 \%$ confidence interval (CI). If $10 \%<P<90 \%, P$ (accuracy [AC], specificity [SP], or sensitivity [SE]) is assumed to follow a normal distribution and the $95 \%$ CI was estimated as follows: $\mathrm{CI}_{95 \%}=P \pm 2 \times \operatorname{sqr}(P(1-P) / n)$, with $n=\mathrm{N}, \mathrm{N}+$, or $\mathrm{N}-$ for AC, $\mathrm{SE}$, or SP, respectively. If $P>90 \%$, tables of binomial distribution were used and a unilateral limit of confidence was indicated.

${ }^{\mathrm{b}}$ For both methods, number of samples $=420$.

${ }^{c} \mathrm{PA}=$ positive accord and $\mathrm{ND}=$ negative deviation

${ }^{\mathrm{d}} \mathrm{PD}=$ positive deviation and $\mathrm{NA}=$ negative accord .

${ }^{e}$ Relative sensitivity (SE) is computed according to Mc Clure (30) and as follows: $\mathrm{SE}=100 \% \times \mathrm{PA} / \mathrm{N}+$, with $\mathrm{N}+=\mathrm{PA}+\mathrm{ND}$.

${ }^{\mathrm{f}}$ Relative specificity (SP) is computed according to Mc Clure (30) and as follows: $\mathrm{SP}=100 \% \times \mathrm{NA} / \mathrm{N}-$, with N- $-\mathrm{NA}+\mathrm{PD}$.

g Relative accuracy (AC) is computed according to Mc Clure (30) and as follows: $\mathrm{AC}=100 \% \times(\mathrm{PA}+\mathrm{NA}) / \mathrm{N}$, with $\mathrm{N}=\mathrm{NA}+\mathrm{PA}+\mathrm{PD}+\mathrm{ND}$.

TABLE 5. Results of the real-time and conventional polymerase chain reaction (PCR) tests with seed samples of different Pinus spp. and from different origins ${ }^{\mathrm{a}}$

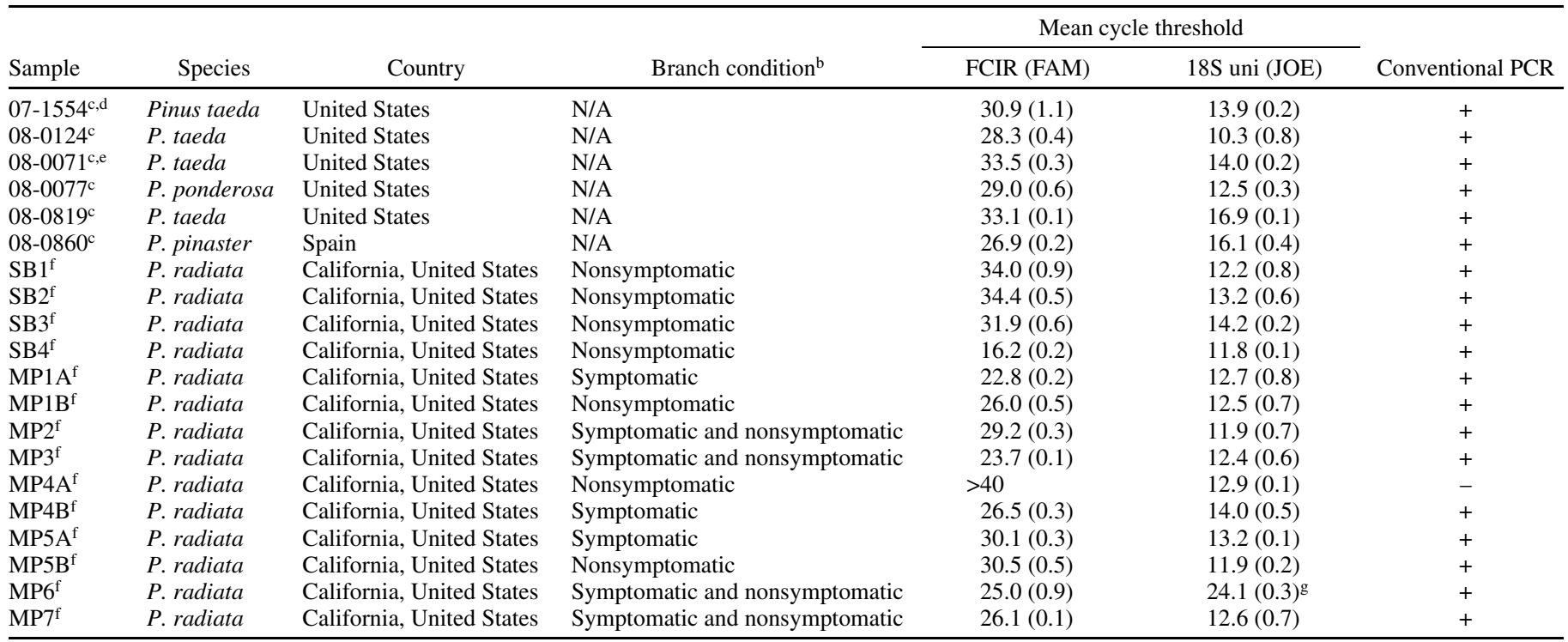

${ }^{a}$ Commercial samples that were found negative $(n>80)$ are not included in the table.

b Samples of Pinus radiata seed were extracted from (i) cones borne on branches with symptoms of pitch canker, (ii) branches without symptoms, or (iii) a mix of symptomatic and healthy branches. N/A = not applicable.

c Commercial seed sample.

${ }^{\mathrm{d}}$ Sample whose real-time PCR product was sequenced and deposited as GenBank accession no. EU650681.

e Sample whose real-time PCR product was sequenced and deposited as GenBank accession no. EU650682.

${ }^{\mathrm{f}}$ Collected from cones manually harvested on individual trees showing symptoms of pitch canker.

$\mathrm{g}$ Sample for which only $1 \mathrm{~g}$ could be collected and analyzed. 
length, the sequence showed $100 \%$ identity with all the sequences of $F$. circinatum isolated from pine deposited in GenBank but only $95 \%$ identity with the closest organisms (i.e., F. bulbicola and a Fusarium sp. isolated from Narcissus, GenBank accessions AY249395 and EF437285, respectively) and less with other phylogenically close Fusarium spp. This result confirmed that the amplicon generated by PCR from naturally infected seed samples originated from $F$. circinatum and was not an artifact or a nonspecific cross amplification. By extension, all the samples whose DNA extract yielded a $\mathrm{Ct}$ following a FCIR-F/-R/-P real-time PCR were considered to be positive for $F$. circinatum.

More than 100 commercial seed samples were analyzed by both real-time and conventional PCR. Six of them yielded positive results with both techniques (Table 5). The $18 \mathrm{~S}$ uni real-time PCR test successfully yielded Ct for the others, indicating that the DNA extract was amplifiable (data not shown); therefore, all the negative samples were considered to be free of F. circinatum, or at least below the detection threshold of the assay.

In addition, 13 of the 14 seed samples collected from infected Pinus radiata in an native stand in California yielded positive results with both PCR techniques (Table 5). Therefore, F. circinatum was found on seed from cones collected on both symptomatic and asymptomatic branches.

\section{DISCUSSION}

This study presents a new, sensitive, and specific detection protocol combining an enrichment procedure with a real-time PCR assay that enables detection of low infestation levels in artificially contaminated seed as well as in seed obtained from naturally infested pine stands. Whereas $F$. circinatum is mostly present on the seed surface for longleaf and shortleaf pine (17), it also infests internal seed tissue (8) in other species. Therefore, seed surface treatments may not be sufficient to eliminate $F$. circinatum propagules, and seed from trees in infested areas will never be free from the risk of contamination (43). Thus, seed testing is a necessary component of an exclusion program to prevent pathogen introductions into countries or localities where pitch canker does not yet occur. Techniques that rely on culturing the pathogen may be insufficient for this purpose owing to the risk of falsenegative results (43). Therefore, there is a need for detection based on other criteria such as diagnostic DNA sequences.

Biological enrichment procedures enhanced the sensitivity of the real-time PCR assay for $F$. circinatum in pine seed samples. Detection of a single infested seed in a 1,000-seed sample was achieved after incubation in a nonselective enrichment medium for $72 \mathrm{~h}$. The number of propagules associated with a single seed is unknown but our procedure deposited an estimated 1,500 to 4,300 spores on each seed. However, the true detection threshold may be lower because seed samples containing 0.5 artificially contaminated seed also yielded positive results (data not shown). In any case, limits of detection may be influenced by the type and the biological state of the propagules present on or in the seed. Incubation times longer than $72 \mathrm{~h}$ might improve the detection threshold but this possibility was not explored in the present study. Nevertheless, using this protocol, $F$. circinatum was successfully detected in naturally infested samples, both from commercial lots and from seed manually collected in infested $P$. radiata stands. This demonstrates that the protocol described in this study is able to detect $F$. circinatum in samples with natural and realistic infection levels. Furthermore, the detection of F. circinatum on seed collected on noninfected branches is consistent with the observations of Storer et al. (43), who postulated that, in areas with infected pine species, airborne conidia of the pathogen may contaminate the seed surface during periods when the cones are opened and may also penetrate the female strobili during pollination.

Our results indicate that more growth of $F$. circinatum was obtained with an enrichment procedure using PD broth than with the semiselective DCP broth. Thus, although PD broth would support the growth of most fungi found in or on the seed, it seems that competition between fungal strains in the medium did not adversely affect the detection threshold in comparison with semiselective medium. Regardless of the enrichment procedure followed, the Macherey-Nagel Plant II DNA extraction kit enabled recovery of higher amounts or better-quality DNA than the Qiagen DNeasy mini kit. This result may not be extrapolated to other plant-pathogen combinations but clearly indicates that different commercial DNA extraction kits should be evaluated prior to implementation of a new PCR-based diagnostic procedure.

The real-time PCR procedure described here targets a combination of $F$. circinatum DNA sequences that should detect the fungus even in a quiescent state, which may not be the case for agar-plating techniques (43). On the other hand, nonviable $F$. circinatum propagules (e.g., killed by a lethal seed treatment) may also be detected. Whereas such a result could be regarded as a "false positive", the presence of pathogen DNA, even if associated with nonviable propagules, may indicate that viable inoculum resides elsewhere in the lot being tested. Consequently, for a pathogen subject to quarantine restrictions, it is appropriate to consider such results as positive, even if viability has not been confirmed. Obviously, the enhanced sensitivity provided by the biological enrichment step would apply only where viable propagules are present.

Even though the protocol described herein should allow for detection of $F$. circinatum with a high probability when it is present in a seed sample, the reliability of a seed assay also must take into consideration the probability of including at least one contaminated seed in the samples selected for testing (19). This issue was beyond the scope of our study, and further research is needed to establish statistically sound sampling methods that take account of a potentially uneven distribution of $F$. circinatum within a seed lot.

The quarantine status for $F$. circinatum demands a highly sensitive but also a highly specific detection test. Our data shows that the dual-labeled probe-based-real-time PCR test developed in this study, run under high-stringency conditions, is highly specific because it did not cross-react with DNA from the phylogenetically close species tested. However, cryptic speciation has been reported within the E mating population of the G. fujikuroi complex (42), and the occurrence of new or yet undescribed Fusarium sp. with IGS sequences identical to those targeted in F. circinatum cannot be completely ruled out. Nevertheless, sequencing of the real-time PCR product should confirm the identity of the species.

Finally, the real-time PCR test developed here appeared very sensitive, with repeatable $\mathrm{Ct}$ values consistently obtained with as little as $8 \mathrm{fg}$ of DNA, in contrast to a detection limit of $10 \mathrm{pg}$ obtained using the CIRC1A/CIRC4A PCR test, in either conventional or SYBR green real-time format (39). As previously observed by Bilodeau et al. (9), SYBR green may inhibit DNA polymerase during PCR and, thus, results in a lower specificity.

The exponential feature of PCR amplification, together with the minute amount of target molecules in DNA extracts from the seed samples with the lowest contamination levels, means that trivial variations in reaction components and thermal cycling conditions and mispriming events during the early stage of the PCR may greatly influence the final yield of the amplified product and the mean $\mathrm{Ct}$ value. In this study, only very slight variations were observed between triplicates analyses within the same run or between different runs, which supports the robustness of the protocol. Nevertheless, official analyses should conform to stringent criteria such as a minimum detection threshold and tests to confirm the quality of each DNA extract. In this view, along with the $F$. circinatum probe, a new primer-probe combination was designed to target a highly conserved $18 \mathrm{~S}$ rDNA region for a wide range of organisms. This 18S-uni real-time test should be conducted in parallel on the DNA extracts to serve as a DNA extract quality control. 


\section{ACKNOWLEDGMENTS}

We thank the Direction Générale de l'Alimentation, sous Direction de la Qualité et de la Protection des Végétaux (Ministry of Agriculture, France) for supporting this research financially; K. O'Donnell for supplying numerous Fusarium isolates used in this study; N. Schenck, C. Saurat, M. Loiseau, and D. Cohen (LNPV) for the fungal and plant DNA; and R. Germain (Vilmorin S.A.) for providing the pine seed.

\section{LITERATURE CITED}

1. Andrews, S., and Pitt, J. 1986. Selection medium for Fusarium species and dematiaceous Hyphomycetes from cereals. Appl. Environ. Microbiol. 5:1235-1238.

2. Anonymous. 1995. Commission Directive 95/44/EC of 26 July 1995 establishing the conditions under which certain harmful organisms, plants, plant products and other objects listed in Annexes I to V to Council Directive 77/93/EEC may be introduced into or moved within the Community or certain protected zones thereof, for trial or scientific purposes and for work on varietal selections. Pages 34-46 in: CELEXEUR Official Journal L 184, 3 August 1995.

3. Anonymous. 2003. Microbiology of food and animal feeding stuffsprotocol for the validation of alternative methods. International Standards Organization 16140.

4. Anonymous. 2004. Report on the interception of Fusarium circinatum (Pitch Canker) on imported seedlings of Douglas fir (Pseudotsuga menziesii). Published online by MAF Biosecurity New Zealand. http:// www.biosecurity.govt.nz/imports/forests/emergency-measure.htm.

5. Anonymous. 2006. First report of Gibberella circinata in France. Published online by the European and Mediterranean Plant Protection Organization. http://archives.eppo.org/EPPOReporting/2006/Rsf-0605.pdf.

6. Anonymous. 2007. Commission Decision of 18 June 2007 on provisional emergency measures to prevent the introduction into and the spread within the Community of Gibberella circinata Nirenberg \& O'Donnell (2007/433/EC). Official J. Eur. Union 161:66-69.

7. Barnard, E. L., and Blakeslee, G. M. 1980. Pitch canker of slash pine seedling: a new disease in forest tree nurseries. Plant Dis. 64:695-696.

8. Barrows-Broaddus, J. B., and Dwinnell, L. D. 1985. Branch dieback and cone and seed infection caused by Fusarium moniliforme var. subglutinans in a loblolly pine seed orchard in South Carolina. Phytopathology 75:1104-1108.

9. Bilodeau, G. J., Lévesque, C. A., de Cock, A. W. A. M., Duchaine, C., Brière, S., Uribe, P., Martin, F. N., and Hamelin, R. C. 2007. Molecular detection of Phytophthora ramorum by real-time polymerase chain reaction using TaqMan, SYBR green, and molecular beacons. Phytopathology 97:632-642.

10. Britz, H., Coutinho, T. A., Gordon, T. R., and Wingfield, M. J. 2001. Characterization of the pitch canker fungus, Fusarium circinatum, from Mexico. S. Afr. J. Bot. 67:609-614.

11. Britz, H., Coutinho, T. A., Wingfield, M. J., and Marasas, W. F. O. 2002. Validation of the description of Gibberella circinata and morphological differentiation of the anamorph Fusarium circinatum. Sydowia 54:9-22.

12. Bustin, S. A. 2000. Absolute quantification of mRNA using real-time reverse transcription polymerase chain reaction assays. J. Mol. Endocrinol. 25:169-193.

13. Carlucci, A, Colatruglio, L, and Frisullo, S. 2007. First report of pitch canker caused by Fusarium circinatum on Pinus halepensis and P. pinea in Apulia (Southern Italy). Plant Dis. 91:1683.

14. Corpet, F. 1988. Multiple sequence alignment with hierarchical clustering. Nucleic Acids Res. 16:1081-1089.

15. Correll, J. C., Gordon, T. R., McCain, A. H., and Jacobsen, D. J. 1992. Examination of genetic diversity in populations of the pitch canker pathogen Fusarium subglutinans. Phytopathology 82:415-420.

16. Coutinho, T. A., Wingfield, M. J., Viljoen, A., Britz, H., and Marasas, W. F. O. 1997. Pitch canker of pines: A Southern African perspective. Pages 29-35 in: Proc. ISTA Tree Seed Pathol. Meet. Opocno, Czech Republic. Z. Prochazkova and J. R. Sutherland, eds. International Seed Testing Association, Zurich.

17. Dwinnell, L. D., Fraedrich, S. W., and Adams, D. 2001. Disease of pines caused by the pitch canker fungus. Pages 225-232 in: Fusarium Paul E. Nelson Memorial Symposium. B. A. Summerell, J. F. Leslie, D Backhouse, W. L. Bryden, and L. W. Burgess, eds. The American Phytopathological Society, St. Paul, MN.

18. Dwinell, L. D., and Phelps, W. R. 1977. Pitch canker of slash pine in Florida. J. For. 75:488-489.

19. Geng, S., Campbell, R. N., Carter, M., and Hills, F. J. 1983. Qualitycontrol programs for seedborne pathogens. Plant Dis. 67:236-242.

20. Gordon, T. R. 2006. Pitch canker disease of pines. Phytopathology 96:657-659.
21. Gordon, T. R., Kirkpatrick, S. C., Aegerter, B. J., Wood, D. L., and Storer, A. J. 2006. Susceptibility of Douglas-fir (Pseudotsuga menziesii) to pitch canker, caused by Gibberella circinata (anamorph $=$ Fusarium circinatum). Plant Pathol. 55:231-237.

22. Gordon, T. R., Storer, A. J., and Okamoto, D. 1996. The population structure of the pitch canker pathogen, Fusarium subglutinans f. sp. pini, in California. Mycol. Res. 100:850-854.

23. Gordon, T. R., Storer, A. J., and Wood, D. L. 2001. The pitch canker epidemic in California. Plant Dis. 85:1128-1139.

24. Guerra-Santos, J. J. 1999. Pitch canker on Monterey pines in Mexico. Pages 58-61 in: Forestry and Forest Products. Current and Potential Impacts of Pitch Canker in radiata Pine. M. E. Devey, A. C. Matheson, and T. R. Gordon, eds. Tech. Rep. Vol. 112. CSIRO, Canberra, Australia.

25. Hepting, G. H., and Roth, E. R. 1946. Pitch canker, a new disease of some southern pines. J. For. 44:742-744.

26. Hodge, G. R., and Dvorak, W. S. 2000. Differential responses of Central American and Mexican pine species and Pinus radiata to the pitch canker fungus. New. For. 19:241-258.

27. Huang, J. W., and Kuhlman, E. G. 1990. Fungi associated with dampingoff slash pine seedlings in Georgia. Plant Dis. 74:27-30.

28. Ioos, R., Belhadj, A., and Menez, M. 2004. Occurrence and distribution of Microdochium nivale and Fusarium species isolated from barley, durum, and soft wheat grains in France from 2000 to 2002. Mycopathologia 158:351-362.

29. Landeras, E., Garcia, P., Fernandez, Y., Brana, M., Fernando-Alonso, O., Mendez-Lodos, S., Perez-Sierra, A., Leon, M., Abad-Campos, P., Berbegal, M., Beltran, R., Garcia-Jimenez, J., and Armengol, J. 2005. Outbreak of pitch canker caused by Fusarium circinatum on Pinus spp. in Northern Spain. Plant Dis. 89:1015.

30. McClure, F. D. 1990. Design and analysis of qualitative collaborative studies: Minimum collaborative program. J. Assoc. Off. Anal. Chem. 73:953-960

31. Muramoto, M., and Dwinell, L. D. 1990. Pitch canker of Pinus luchuensis in Japan. Plant Dis. 74:530.

32. Nirenberg, H. I. 1981. A simplified method for identifying Fusarium spp. occurring on wheat. Can. J. Bot. 59:1599-1609.

33. Nirenberg, H. I., and O'Donnell, K. 1998. New Fusarium species and combinations with the Gibberella fujikuroi species complex. Mycologia 90:434-458

34. O’Donnell, K., Cigelnik, E., and Nirenberg, H. I. 1998. Molecular systematic and phylogeography of the Gibberella fujikuroi species complex. Mycologia 90:465-493.

35. Pérez-Sierra, A., Landeras, E., Leon, M., Berbegal, M., Garcia-Jiménez, J., and Armengol, J., 2007. Characterization of Fusarium circinatum from Pinus spp. in Northern Spain. Mycol. Res. 111: 832-839.

36. Schaad, N. W., Berthier-Schaad, Y., Sechler, A., and Knorr, D. 1999. Detection of Clavibacter michiganensis subsp. sepedonicus in potato tubers by BIO-PCR and an automated real-time fluorescent detection system. Plant Dis. 83:1095-1100.

37. Schaad, N. W., Cheong, S. S., Tamaki, S., Hatriloukas, E., and Panopoulos, N. J. 1995. A combined biological and enzymatic amplification (BIO-PCR) technique to detect Pseudomonas syringae pv. phaseicola in bean extracts. Phytopathology 85:243-248.

38. Schena, L., Nigro, F., Ippolito, A., and Gallitelli, D. 2004. Real-time quantitative PCR: a new technology to detect and study phytopathogenic and antagonistic fungi. Eur. J. Plant Pathol. 110:893-908.

39. Schweigkofler, W., O'Donnell, K., and Garbelotto, M. 2004. Detection and quantification of airborne conidia of Fusarium circinatum, the causal agent of pine pitch canker, from two California sites by using a real-time PCR approach combined with a simple spore trapping method. Appl. Environ. Microbiol. 70:3512-3520.

40. Shapira, R., Paster, N., Eyal, O., Mennasherov, M., Mett, A., and Salomon, R. 1996. Detection of aflatoxigenic molds in grains by PCR. Appl. Environ. Microbiol. 62:3270-3273.

41. Steenkamp, E. T., Wingfield, B. D., Coutinho, T. A., Wingfield, M. J., and Marasas, W. F. O. 1999. Differentiation of Fusarium subglutinans f. sp. pini by histone gene sequence data. Appl. Environ. Microbiol. 65:3401-3406.

42. Steenkamp, E. T., Wingfield, B. D, Desjardin, A. E., Marasas, W. F. O., and Wingfield, M. J. 2002. Cryptic speciation in Fusarium subglutinans. Mycologia 94:1032-1043.

43. Storer, A. J., Gordon, T. R., and Clarck, S. L. 1998. Association of the pitch canker fungus, Fusarium subglutinans f. sp. pini with Monterey pine seeds, and seedlings in California. Plant Pathol. 47:649-656.

44. White, T. J., Bruns, T., Lee, S., and Taylor, J. 1990. Amplification and direct sequencing of fungal ribosomal RNA genes for phylogenetics. Pages 315322 in: PCR Protocols: A Guide to Method and Applications. M. A. Innis, D. H. Gelfand, J. J. Sninsky, and T. J. White, eds. Academic Press, NY.

45. Wingfield, M. J., Jacobs, A., Coutinho, T. A., Ahumada, R., and Wingfield, B. D. 2002. First report of the pitch canker fungus, Fusarium circinatum, on pines in Chile. Plant Pathol. 51:397 